\title{
FUNCTIONS OF MUNICIPAL GEOGRAPHIC INFORMATION SYSTEMS THROUGH THE PRISM OF THEIR USAGE ANALYSIS
}

\author{
Andrii ORESHCHENKO \\ Taras Shevchenko National University of Kyiv \\ logograd@ukr.net
}

\begin{abstract}
Today, the ways of using the municipal geoinformation systems and their functions have not been sufficiently described in the literature. In given paper, functions of GIS are screened and discussed based on scientific publications and learning materials. Additionally they studied the appropriation of GIS, solved problems, target group or production process in which indicated operation of these programs. As far as analogic functions often have different names in different sources, ther were unified by merging in categories and reducing to generalized and laconic representation. We screened 45 scientific publications and 10 textbooks, and identified 62 functions. They were divided in 3 categories depending on their final usage result. Systemic functions (13) are those typical for software: queries, visualization and data collecting, import-export. Applied functions (17) allow getting more sensible result, e.g., map ready for use (cartographic function), model (modeling function), new regular occurrence or characteristic of an object (spatial analysis function), or data set (data management function). More attention is paid to high-level functions (32) because they are related to the final aim of designing the municipal GIS: production automatization, economic, research, reference, consolidation etc. The explanation is iven for the most complicated function definitions. The discussion section deals with the issues related to defining and classification of functions and ambiguous interpretation of them. In the conclusion some reflections on high GIS popularity are presented.
\end{abstract}

Key words: GIS, municipality, function, usage, management, instrument.

DOI: https://doi.org/10.17721/2413-7154/2017.78.35-46

UDC: $913+528.946+353.9$

\section{ВИЯВЛЕННЯ ФУНКЦІЙ МУНЦИИАЛЬНИХ ГЕОГРАФІЧНИХ ІНФОРМАЦІЙНИХ СИСТЕМ ШЛЯХОМ АНАЛІЗУ РЕЗУЛЬТАТІВ ЇХ ВИКОРИСТАННЯ}

\author{
Андрій ОРЕЩЕНКО \\ Київський національний університет імені Тараса Шевченка \\ logograd@ukr.net
}

\begin{abstract}
Анотація: Способи використання муніципальних геоінформаційних систем та їх функції розкриті на сьогодні не повністю. Функції цих програм виявляли шляхом аналізу способів їх використання, описаних у наукових публікаціях та навчальних матеріалах. Додатково вивчали призначення ГІС, вирішену проблему, цільову аудиторію або виробничі процесі, у яких описано застосування цих програм. Оскільки у різних джерелах аналогічні функції можуть мати різні назви, їх уніфікували - об'єднували в категорії і приводили до узагальненого і лаконічного вигляду. У результаті огляду понад 45 досліджень та 10 підручників) були виявлені 62 функції. Їх поділили на 3 групи залежно від приналежності до кінцевого результату. До системних віднесені типові функції для програмного забезпечення: запити, візуалізація і збір даних, імпорт-експорт. Всього автори статей і книг згадали 13 функцій. Прикладні функції (17) дозволяють отримати більш осмислений результат: картографічна - готову до використання карту, моделювання - модель, просторовий аналіз - нову закономірність або характеристику об'єкта, управління даними - набір даних. Високорівневим функціям була приділена більша увага, бо вони вказують на кінцеву мету розроблення муніципальних ГІС: автоматизацію виробництва, економічну, дослідницьку, довідкову, консолідаційну (32). Складним для розуміння понятям дано пояснення. В обговоренні результатів вказано проблеми у виділенні та класифікації функцій і їх неоднозначного трактування. У висновках викладено причини популярності геоінформаційних систем.
\end{abstract}

Ключові слова: ГІС, муніципалітет, функція, використання, управління, інструмент.

DOI: https://doi.org/10.17721/2413-7154/2017.78.35-46

UDC: $913+528.946+353.9$

Вступ. Комфортне проживання населення на певній території $є$ одною із важливих задач урбаністики. Для реалізації цієї потреби населення певної території (муніципалітету) може делегувати відповідні повноваження органам влади. Функція останніх в цій частині, так чи інакше, зводиться до

(C) А. Орещенко вирішення поточних задач і управління розвитком території. Ці задачі включають в себе ряд менших: збір актуальної інформації про стан довіреної території, виявлення проблем i пріоритетних потреб, прийняття рішень, планування діяльності, складання проектів, залучення інвесторів, координація діяльності жителів території та багато інших. Одним із інструментів для спрощення такої 
діяльності є геоінформаційні системи. Відповідно, за призначенням, цільовою аудиторією та розміром території (і масштабом вирішуваних задач) такі ГІС можна назвати муніципальними.

Для проектування і розроблення такої ГIC, крім технічних характеристик, потрібно точно знати ті функції, які будуть на неї покладені. Теоретично перелік корисних функцій можна встановити без значних зусиль, проте залишиться відкритим питання їх затребуваності. Для виявлення дійсно потрібних функцій слід вивчити попередній практичний досвід із реалізації подібних проектів.

Без проведення досліджень можна сказати, що погляд на використання такого інструменту має суттєво відрізнятися у розробників і користувачів. Питання такого роду завжди виникають під час проектування і розроблення складних програм.

Мета і завдання дослідження. Суть проблеми полягає у тому, що в навчальних виданнях по геоінформаційних системах, а також у керівництвах користувача функції ГІС викладені з точки зору геоінформатики. До цього списку входять введеннявиведення даних, візуалізація останніх у вигляді карт та геопросторовий аналіз. Для спеціаліста 3 іншої галузі знань ці нові поняття є незрозумілими; крім того, вони не несуть прикладного навантаження (не $\epsilon$ корисними для кінцевого користувача). Корисними можуть бути технічне обгрунтування прийнятого рішення, вирішення прикладної задачі, отримані нові знання, формування сприйняття певної проблеми цільовою аудиторією, платформа для об'єднання громадян 3 метою вирішення певної задачі, можливість отримати довідкову інформацію тощо. Доповнення класифікації функцій геосистем, прийнятої в геоінформатиці, дозволило би наблизити теорію використання ГІС до кінцевого користувача.

Теоретико-методологічні основи дослідження. Використанню геоінформаційних систем для вирішення виробничих задач i викладенню результатів прикладних досліджень присвячено чи не найбільше наукових публікацій. Причиною такої популярності геоінформаційних інструментів потенційно може бути затребуваність функцій, які має цей клас програмного забезпечення. Ці функції найбільш детально викладені в спеціалізованих виданнях, на зразок [Даценко, 2013; Digital tools, 2010; Іщук 2003; Лабенко, 2012; Остроух, 2011, Павленко, 2013; Samoilenko, 2015; Шипулін, 2014].

Найбільш досконалим, на думку автора, $\epsilon$ видання [Іщук, 2003]. В ньому перераховані фактично всеможливі функції ГІС з точки зору геоінформатики. Крім повноти, перевагою $\epsilon$ стиль викладення матеріалу 3 високим рівнем абстрагування і конкретизації. Не дивлячись на відсутність у класифікації функцій і способів використання ГІС 3 інших галузей діяльності людини, в книзі можна прослідкувати важливу концепцію. Вона полягає у значенні ГІС як інструменту, який доповнює розумові можливості спеціаліста. Тобто аналітичні, творчі, професійні здібності фахівця, які використовуються для вирішення прикладних задач, доповнюються певними функціями, які грунтуються на обчислювальній потужності та можливостях геоінформаційного програмного забезпечення. Таке поєднання може суттєво підвищити якість і продуктивність вирішення певних задач. Тому в ході дослідження, за можливості, слід виявити функції інформаційно-аналітичного характеру.

У підручнику (Самойленко В. М., 2010) розділ, присвячений функціям ГІС відсутній у змісті, проте відповідний матеріал складає більшу частину книги. Розглядається просторовий аналіз, робота $з$ даними, класифікація об'єктів і їх просторовий розподіл, накладання шарів та статистичні поверхні. Проте чіткої класифікації прослідкувати не вдалося.

В підручнику В. Д. Шипуліна наведено кілька класифікацій задач ГІС-аналізу; окрему частину відведено на аналітичні засоби ГІС-аналізу (вимірювання, вибору даних, автоматизованої класифікації, оверлейні, околу, зв’язності.

Автор посібника Л. А. Павленко за основу викладення матеріалу взяв класифікацію функцій, прийняту в ArcGIS. Даценко Л. М. окремо виділяє «Завдання, які вирішує ГІС» в окремому підрозділі та «Функціональні можливості ГІС» як розділ.

Лабенко Д.П. і Тімонін В.О. приділяють увагу аналізу інформації і їі візуалізації у вигляді карт i схем; виготовленню картографічної основи i обробці географічної інформації; засобам отримання карти в умовних знаках безпосередньо в процесі дигиталізації; засобам графічного редагування карт, функціям для отримання геометричних параметрів (координат, відстаней, довжин, площ, кутів).

Таким чином, в із аналізу навчальної літератури не так просто отримати вичерпне уявлення про функції ГІС безвідносно до області використання.

Наукових досліджень, пов'язаних саме із муніципальними ГІС порівняно небагато. Причиною цього може бути деяка понятійна неузгодженість. Муніципальні геоінформаційні системи призначені лише для самокерованих адміністративнотериторіальних одиниць. Проте подібні функції мають регіональні ГІС, яким приділено відносно більше уваги. Ще більш детально розглянуті геоінформаційні системи міст. Таким чином, до поняття «муніципальна ГІС» дотичними є цілий клас понять. Ця проблема піднімається у статті [Кушнірук, 2016]. Додаткові різночитання створює відсутність законодавчого закріплення вказаних термінів. Для поняття «муніципальне утворення» ключовим $\epsilon$ наявність місцевого самоврядування. Саме на місцеві органи влади як на кінцевого користувача i замовника розрахований цей клас геосистем.

Під час аналізу джерел відразу виявилось, що найбільш популярною темою $\epsilon$ вивезення твердих побутових відходів [Sumathi V.R. at. all., 2008; Bhambulkar A. V., 2011; Kanchanabhan T. E., 2010; Kao J.-J., 1997; Ghose M., 2006 та ін.]. Всі вони пов'язані із розрахунком економічно-обгрунтованої схеми збору і доставки сміття до звалищ, тобто описують результати проведеного просторового аналізу. 


\section{Таблиия 1. Системні функції муніципальних ГІС}

\begin{tabular}{|c|c|c|c|}
\hline Приклади згадування функцій у джерелі & Уніфікована назва & Індекс & Кількість \\
\hline Видача на друк результатів пошуку; оцифровка топографічних карт & Введення-виведення & gInOut & $10 ; 3$ \\
\hline Інтерполяція даних і відображення їх у вигляді статистичної поверхні & Відображення даних & gDisp & $1 ; 1$ \\
\hline $\begin{array}{l}\text { Візуалізація напрямів; візуалізація результатів шляхом графічної } \\
\text { інтерпретації; нанесення за координатами }\end{array}$ & Візуалізація & $\mathrm{gVis}$ & $28 ; 7$ \\
\hline $\begin{array}{l}\text { Дані GPS по містах для визначення реальних маршрутів руху } \\
\text { транспорту, визначення маршрутів руху велосипедів, об'єднання даних } \\
\text { в єдиний простір з єдиною геоприв'язкою }\end{array}$ & $\begin{array}{l}\text { Геолокація / } \\
\text { геоприв'язка }\end{array}$ & gGPS & $3 ; 6$ \\
\hline Обробка просторових даних, обробка геоданих & Геообробка & gGeoPr & 5 \\
\hline Допоміжні побудови, буферизація & Графічна & gGraph & $9 ; 4$ \\
\hline Пошук об’єктів надання адмінпослуг за різними критеріями & Запити & gQer & $3 ; 3$ \\
\hline Зйомка [польова]; польовий збір даних & Збір даних & gDtColl & $9 ; 0$ \\
\hline $\begin{array}{l}\text { Підготовка звітних матеріалів, можливість збереження зображення } \\
\text { користувачем у різних растрових форматах }\end{array}$ & Імпорт-експорт & gImEx & $5 ; 0$ \\
\hline $\begin{array}{l}\text { Вимірювання відстаней, площ; функції для отримання геометричних } \\
\text { параметрів (координат, відстаней, довжин, площ, кутів) }\end{array}$ & Картометрична & gMetr & $5 ; 2$ \\
\hline Класифікація та перекласифікація просторових об’єктів у ГІС & Класифікація & gClass & $0 ; 2$ \\
\hline $\begin{array}{l}\text { Перетворення зібраних координат, геоприв’язка; програмні засови } \\
\text { перетворення координат та трансформацій картографічних проектцій }\end{array}$ & $\begin{array}{l}\text { Трансформування } \\
\text { координат }\end{array}$ & gCoo & $6 ; 3$ \\
\hline Зміна геометрії, інтерполяція, екстраполяція, апроксимація & Перетворення даних & $\mathrm{gDtTr}$ & $1 ; 2$ \\
\hline
\end{tabular}

\section{Таблиия 2. Прикладні функції муніципальних ГІС}

\begin{tabular}{|c|c|c|c|}
\hline Приклади згадування функцій у джерелі & Уніфікована назва & Індекс & Кількість \\
\hline Віртуальна модель & $3 \mathrm{D}$ & $\mathrm{a} 3 \mathrm{D}$ & $8 ; 2$ \\
\hline Отримання інформації шляхом аналізу вихідних умов & Генерація даних & aGen & $6 ; 2$ \\
\hline Створення та архівація документів & Документування & $\mathrm{aDoc}$ & $1 ; 0$ \\
\hline $\begin{array}{l}\text { Розвиток перспективного плану є хорошою ілюстрацією реального } \\
\text { курсу реформ }\end{array}$ & Ілюстративна & aPic & $1 ; 0$ \\
\hline $\begin{array}{l}\text { Використання в аналізі одночасно кількох методів: математичних, } \\
\text { статистичних, візуальних, евристичних }\end{array}$ & Інтеграція методів & aIntM & $1 ; 0$ \\
\hline $\begin{array}{l}\text { Вбудоване середовище програмування, простий підхід до розроблення } \\
\text { програм на ГІС-платформі; проектування ГІС }\end{array}$ & Інструментальна & aPrg & $6 ; 0$ \\
\hline $\begin{array}{l}\text { Здатність геоінформаційних систем інтегрувати просторові й } \\
\text { непросторові дані, потреба використання даних про грунти, інженерних } \\
\text { споруд, гідро-геологічних, топографічних і врахування економічних } \\
\text { причин }\end{array}$ & Інтеграція даних & aIntD & $14 ; 3$ \\
\hline $\begin{array}{l}\text { Різні способи відображення просторової інформації; аналіз та розробка } \\
\text { карт; автоматизоване картографування; }\end{array}$ & Картографічна & aMap & $22 ; 6$ \\
\hline $\begin{array}{l}\text { Моделювання процесів; «а якщо?»; дослідження потенційних сценаріїв; } \\
\text { симуляція процесів росту міста; створення і калібрування моделі; } \\
\text { розроблення ГІС-моделі для демонстрації ефективності }\end{array}$ & Моделювання & aModl & $24 ; 7$ \\
\hline $\begin{array}{l}\text { Використовується як репозиатрій для збереження даних про } \\
\text { інфраструктуру, як дороги...; }\end{array}$ & Накопичувальна & aDep & $1 ; 1$ \\
\hline Порівняння отриманих результатів & Порівняння & aCmpr & $1 ; 0$ \\
\hline $\begin{array}{l}\text { Визначення впливу навколишнього середовища на стан здоров'я } \\
\text { населення }\end{array}$ & Прикладна & aApl & $2 ; 2$ \\
\hline $\begin{array}{l}\text { Прокладання варіантів маршрутів до вибраних об’єктів, вибір } \\
\text { оптимального шляху до них за різними критеріями; виділення кластерів, } \\
\text { класифікація [територій]; вирішення логістичних задач, «overlay } \\
\text { analysis»; зонування; просторова статистика }\end{array}$ & Просторовий аналіз & aSpAn & $25 ; 4$ \\
\hline Статистичний аналіз даних по об’єктах; & Статистичний аналіз & aStAn & $1 ; 1$ \\
\hline Пошук альтернативних рішень & Творча & aAlt & $1 ; 1$ \\
\hline Організація і управління даними, растрово-векторні операції; & Управління даними & aDMen & $13 ; 5$ \\
\hline Просторовий та часовий аналіз росту міст & Часовий аналіз & aTemp & $1 ; 2$ \\
\hline
\end{tabular}




\section{Таблиця 3. Високорівневі функції муніципальних ГІС}

\begin{tabular}{|c|c|c|c|}
\hline Приклади згадування функцій у джерелі & Уніфікована назва & Індекс & Кількість \\
\hline $\begin{array}{l}\text { Автоматизація інженерних процесів на ГІС-платформі, підвищення } \\
\text { продуктивності роботи }\end{array}$ & Автоматизація & mAuto & $5 ; 0$ \\
\hline Проникнення ГІС у вирішення адміністративних задач & Адміністративна & mAdm & $2 ; 0$ \\
\hline $\begin{array}{l}\text { Аналітична функція; функція аналізу; технологія для розуміння; оцінка } \\
\text { міської політики; аналіз таких глобальних проблем, як перенаселення, } \\
\text { забруднення довкілля; статистичний аналіз; системний аналіз; } \\
\text { факторний аналіз, кореляційний аналіз }\end{array}$ & Аналіз & mAnlst & $28 ; 8$ \\
\hline Перевірка отриманих даних; перевірка відповідності усім критеріям & Верифікація & $\mathrm{mVrfc}$ & $3 ; 4$ \\
\hline Вирішення широкого спектру інженерних проблем & Вирішення проблем & mPrSolv & $6 ; 0$ \\
\hline ... починається із розпізнавання проблеми; усвідомлення проблеми & Виявлення проблем & mPrRev & $3 ; 1$ \\
\hline $\begin{array}{l}\text { Отримання адресної інформації по об’єктах надання адміністративних } \\
\text { послуг, можливість вибору об'єкта і отримання інформації та документів } \\
\text { по ньому; отримання комплексної інформації про об’єкт; інформаційна } \\
\text { платформа, інформаційне забезпечення; задоволення інформаційних } \\
\text { потреб; }\end{array}$ & Довідкова & mRef & 4 \\
\hline $\begin{array}{l}\text { Виявлення нових взаємозв’язків між об’єктами; виявлення прихованих } \\
\text { закономірностей, в основі яких лежать просторові фактори }\end{array}$ & Дослідницька & mSci & $9 ; 2$ \\
\hline $\begin{array}{l}\text { Досягнення оптимального використання ресурсів муніципалітетами; } \\
\text { обчислити економічну ефективність рішення; }\end{array}$ & Економічна & mEcon & $1 ; 2$ \\
\hline Розвиток; реалізація проектів & Імплементаційна & mRealiz & $3 ; 1$ \\
\hline Інноваційні процеси в містах & Інноваційна & mInv & $1 ; 0$ \\
\hline $\begin{array}{l}\text { Для ... поширення інформації; знання муніципалітетами економічних } \\
\text {... факторів; }\end{array}$ & Інформаційна & mInf & $7 ; 0$ \\
\hline Планування, підтримка і обслуговування комунікаційних мереж & Інфраструктурна & mInfr & $0 ; 0$ \\
\hline Налагодження співробітництва між владою і громадами & Колабораційна & mColl & $2 ; 0$ \\
\hline Зниження витрат на громадський транспорт & Комерційна & mProf & $7 ; 1$ \\
\hline Комунікація між мешканцями і владою; реалізація зворотнього зв'язку; & Комунікаційна & $\mathrm{mComm}$ & $2 ; 0$ \\
\hline $\begin{array}{l}\text { Подолання розриву між секторами економіки та управління; залучення } \\
\text { громадськості до прийняття рішень; залучення громади до виконання } \\
\text { суспільних робіт; організація спільної роботи спеціалістів із кількох } \\
\text { галузей. }\end{array}$ & Консолідаційна & mCons & $3 ; 1$ \\
\hline $\begin{array}{l}\text { Постійний моніторинг технічного стану і економічного наповнення } \\
\text { інфраструктури; оперативне відображення кримінальної обстановки; } \\
\text { відображення даних в реальному часі }\end{array}$ & Моніторинг & mMon & $10 ; 1$ \\
\hline $\begin{array}{l}\text { Зменшення часу на організацію вивезення сміття; виявити місце } \\
\text { оптимального розташування новго родовища; }\end{array}$ & Оптимізація & $\mathrm{mOpt}$ & $0 ; 1$ \\
\hline $\begin{array}{l}\text { Залучення громади до виконання суспільних робіт, організація, } \\
\text { планування міст за колективною участю; залучення населення до } \\
\text { управління територією }\end{array}$ & Організаційна & mOrg & $2 ; 3$ \\
\hline $\begin{array}{l}\text { Оцінка можливості використання досліджуваного регіону; оцінка } \\
\text { вихідних даних; оцінка ефективності діяльності міліції; }\end{array}$ & Оцінка & mMark & $8 ; 2$ \\
\hline $\begin{array}{l}\text { Прийняття науково і методологічно обгрунтованих управлінських } \\
\text { рішень; багатокритеріальний аналіз рішень }\end{array}$ & $\begin{array}{l}\text { Підтримка } \\
\text { рішень }\end{array}$ & mDSupp & $14 ; 4$ \\
\hline $\begin{array}{l}\text { Геоінформаційне забезпечення планування, урбаністичне планування, } \\
\text { планування розвитку міської території; }\end{array}$ & Планування & mPlan & $17 ; 2$ \\
\hline Надання послуг населенню; обслуговування певних груп населення & Послуги & mServ & $2 ; 0$ \\
\hline $\begin{array}{l}\text { Прогнозування й оцінка наслідків ухвалених рішень у сфері охорони } \\
\text { навколишнього середовища, прогнозування розвитку та наслідків } \\
\text { економічних ситуацій, }\end{array}$ & Прогнозування & mFcast & $2 ; 0$ \\
\hline $\begin{array}{l}\text { Розробка містобудівельних проектів; планування розвитку; } \\
\text { геоінформаційне забезпечення планування і управління комплексним } \\
\text { розвитком територій }\end{array}$ & Проектування & mInstr & $5 ; 3$ \\
\hline $\begin{array}{l}\text { Розроблення і реалізація концепцій; вирішення інженерних задач, } \\
\text { вирішення задач, пов'язаних із забезпеченням інженерної діяльності, } \\
\text { розроблення рішень }\end{array}$ & $\begin{array}{ll}\text { Розроблення } & \text { продуктів } \\
\text { (інжиніринг) } & \end{array}$ & mEng & $8 ; 3$ \\
\hline ... що забезпечує поглиблене розуміння проблеми & Розуміння проблем & mAva & $1 ; 0$ \\
\hline $\begin{array}{l}\text { Управління розвитком території, розвиток території; інтеграція бізнес- } \\
\text { процесів; ефективне управління; оптимізація розвитку міст; }\end{array}$ & Управління & mMngm & $23 ; 4$ \\
\hline Передача виявлених аспектів проблеми & Формування бачення & mVision & $2 ; 1$ \\
\hline Залучення вільних людських ресурсів до вирішення проблеми & Формування зайнятості & mEmpl & $0 ; 1$ \\
\hline ... розширили обмеження нашого розуміння & Формування світогляду & $\mathrm{mWV}$ & $0 ; 1$ \\
\hline
\end{tabular}




\section{Таблиця 4. Перелік функцій у наукових публікаціях}

\begin{tabular}{|c|c|c|}
\hline Галузі знань або науки & Назва джерела & Функції ГІС \\
\hline Геоінформатика & $\begin{array}{l}\text { Геоінформаційні системи і технології в управлінні } \\
\text { муніципальних утворень }\end{array}$ & $\begin{array}{l}\text { AIntD, mAnlst, aModl, mMngm, mRef; mInstr, } \\
\text { mDSupp, mPlan, mMon, aApl. }\end{array}$ \\
\hline Геоінформатика & GIS Steering smart future for smart Indian cities & $\begin{array}{l}\text { mRealiz, GDtColl, mPlan, mDSupp, mInf, mEng, } \\
\text { mMngm, aModl. }\end{array}$ \\
\hline Геоінформатика & 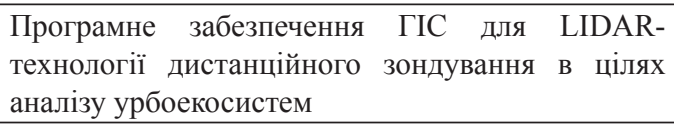 & $\begin{array}{l}\text { a3D, mAuto, mAnlst, gInOut, gVis, gGeoPr, } \\
\text { gImEx, aIntD, gCoo, aModl, mMon, aGen, } \\
\text { mDSupp, aSpAn, aDMen. }\end{array}$ \\
\hline Геоінформатика & $\begin{array}{l}\text { Development and use of a geoinformation system for } \\
\text { revealing urban problems }\end{array}$ & $\begin{array}{l}\text { MAnlst, mPrRev, mPrSolv, gVis, gGraph, } \\
\text { gDtColl, aPrg, aIntD, aMap, gMetr, mProf, } \\
\text { gDtTr, aSpAn, mMngm, aDMen. }\end{array}$ \\
\hline Науки про Землю & $\begin{array}{l}\text { Linking GIS and water resources management } \\
\text { models: an object-oriented method }\end{array}$ & $\begin{array}{l}\text { mAnlst, gInOut, mSci, mPrSolv, mEng, aPrg, } \\
\text { aMap, aModl, mDSupp, mPlan, aSpAn, } \\
\text { mMngm, aDMen. }\end{array}$ \\
\hline Науки про Землю & $\begin{array}{l}\text { Spatial Distribution Analysis of Groundwater Quality } \\
\text { Index Using GIS: A Case Study of Ranchi Municipal } \\
\text { Corporation (RMC) Area. }\end{array}$ & $\begin{array}{l}\text { mAnlst, mVrfc, gVis, aMap, aModl, aDep, } \\
\text { mMark, mPlan, mDSupp, aSpAn, mMngm, } \\
\text { aDMen. }\end{array}$ \\
\hline Науки про Землю & $\begin{array}{l}\text { Assessment of flood risk in Hat Yai municipality, } \\
\text { Southern Thailand, using GIS }\end{array}$ & $\begin{array}{l}\text { GVis, aSpAn, mMngm, gImEx, aIntD, aModl, } \\
\text { a3D, gInOut. }\end{array}$ \\
\hline Державне управління & $\begin{array}{lcc}\text { Smart City: } & \text { використання } & \text { інформаційно- } \\
\begin{array}{l}\text { комунікативних } \\
\text { самоврядуванні }\end{array} & \text { технологій } & \text { у місцевому }\end{array}$ & $\begin{array}{l}\text { MDSupp, mPlan, gVis, aModl, mAnlst, mMon, } \\
\text { aCmpr, aIntD, aMap, a3D, gMetr, aDMen, gVis, } \\
\text { gGraph, gMetr. }\end{array}$ \\
\hline Державне управління & 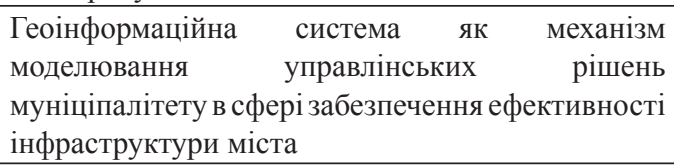 & $\begin{array}{l}\text { MMngm, mDSupp, mComm, aModl, mSci, } \\
\text { mMon, gVis, aStAn, mRef, GImEx, gInOut, } \\
\text { mComm. }\end{array}$ \\
\hline Державне управління & $\begin{array}{l}\text { Смарт-сіті чи електронне місто: сучасні підходи } \\
\text { до розуміння впровадження е-урядування на } \\
\text { місцевому рівні }\end{array}$ & $\begin{array}{l}\text { mColl, mMngm, mDSupp, aModl, mFBack, } \\
\text { gQer, mRef. }\end{array}$ \\
\hline Державне управління & $\begin{array}{l}\text { GIS-Based Engineering Management Service } \\
\text { Functions: Taking GIS beyond Mapping for } \\
\text { Municipal Governments }\end{array}$ & $\begin{array}{l}\text { mAuto, mAdm, mAnlst, gVis, mEng, mInf, } \\
\text { gQer, gDtColl, aMap, mProf, mCons, aModl, } \\
\text { mOrg, mPlan, mServ, aSpAn, mMngm, aIntD. }\end{array}$ \\
\hline Державне управління & $\begin{array}{l}\text { Functions of E-Government: A Study of Municipal } \\
\text { Practices }\end{array}$ & mAdm, mAnlst, mServ, mMngm. \\
\hline Екологія & $\begin{array}{l}\text { A GIS based transportation model for solid waste } \\
\text { disposal - A case study on Asansol municipality }\end{array}$ & GVis, aSpAn, mMngm. \\
\hline Екологія & $\begin{array}{l}\text { Network geographic information system for landfill } \\
\text { siting }\end{array}$ & $\begin{array}{l}\text { mAnlst, mAuto, gInOut, mPrSolv, gVis, gGraph, } \\
\text { aIntD, mInf, aMap, gMetr, mMark, mDSupp, } \\
\text { aSpAn, mMngm. }\end{array}$ \\
\hline Державне управління & $\begin{array}{l}\text { Optimum municipal solid waste collection using } \\
\text { geographical information system (GIS) and vehicle } \\
\text { tracking for Pallavapuram municipality }\end{array}$ & MPlan, gVis, aSpAn. \\
\hline Геоінформатика & $\begin{array}{l}\text { Multi-attribute Decision Analysis in GIS: Weighted } \\
\text { Linear Combination and Ordered Weighted } \\
\text { Averaging }\end{array}$ & $\begin{array}{l}\text { mAnlst, gVis, mPrSolv, mPrRev, aGen, aMap, } \\
\text { aModl, mMark, mDSupp, aSpAn, aDMen. }\end{array}$ \\
\hline Урбаністика & $\begin{array}{l}\text { Оцінка просторової диференціації благоустрою } \\
\text { території Харкова за допомогою ГІС-засобів }\end{array}$ & mEng, gGraph, mAnlst, aMap, aModl. \\
\hline Картографія & $\begin{array}{l}\text { Навчальний посібник «Основи геоінформаційних } \\
\text { систем і технологій» як приклад реалізації } \\
\text { сучасних методів навчання в } \\
\text { інформатизації освіти }\end{array}$ & MAnlst, aSpAn, gQer, mRef, mInstr. \\
\hline Геоінформатика & $\begin{array}{l}\text { Геоінформаційні технології в реалізації завдань } \\
\text { муніципальної влади і рекреаційної діяльності }\end{array}$ & $\begin{array}{l}\text { gVis, aDMen, aModl, mAnlst, mPlan, gImEx, } \\
\text { 3D. }\end{array}$ \\
\hline $\begin{array}{l}\text { Соціально-економічна } \\
\text { географія }\end{array}$ & $\begin{array}{l}\text { Theoretical aspects for use technologies formation } \\
\text { and implementation of urban development land } \\
\text { monitoring }\end{array}$ & $\begin{array}{l}\text { mAnlst, gInOut, aGen, gGraph, aDoc, aMap, } \\
\text { mMon, mEng (aApl), mDSupp, mPlan, aSpAn, } \\
\text { mMngm. }\end{array}$ \\
\hline $\begin{array}{l}\text { Соціально-економічна } \\
\text { географія }\end{array}$ & $\begin{array}{l}\text { An Analysis of Inter-Municipal Migration Flows in } \\
\text { Japan Using GIS and Spatial Interaction Modeling }\end{array}$ & gVis, mSci, aIntD, aMap, aSpAn. \\
\hline $\begin{array}{l}\text { Соціально-економічна } \\
\text { географія }\end{array}$ & Use of GIS in urban territory development research & mAnlst, aPrg, mPlan, mFcast, mMngm. \\
\hline $\begin{array}{l}\text { Соціально-економічна } \\
\text { географія }\end{array}$ & $\begin{array}{l}\text { Просторові трансформації урбанізованих } \\
\text { територій України периферійно-індустріального } \\
\text { типу (на прикладі міст Запоріжжя і Жовті Води. }\end{array}$ & mAnlst, mSci, gDtColl, aModl, mMark, aSpAn. \\
\hline
\end{tabular}




\begin{tabular}{|c|c|c|}
\hline & & Продовження Таблиц̧і 4 \\
\hline Галузі знань або науки & Назва джерела & Функції ГІС \\
\hline $\begin{array}{l}\text { Соціально-економічна } \\
\text { географія }\end{array}$ & $\begin{array}{l}\text { Трансформації міського простору на прикладі } \\
\text { тестової ділянки в м. Луцьк }\end{array}$ & mAnlst, gVis, mSci, gDtColl, aMap, aSpAn. \\
\hline $\begin{array}{l}\text { Соціально-економічна } \\
\text { географія }\end{array}$ & $\begin{array}{l}\text { Decentralization reform in Ukraine: assessment of } \\
\text { the chosen transformation model }\end{array}$ & gVis, aPic, aMap, mPlan, mVision. \\
\hline Технічні науки & $\begin{array}{l}\text { Municipal solid waste collection routes optimized } \\
\text { with ArcGIS Network Analyst }\end{array}$ & mAuto, gVis, aMap, aModl, aSpAn, aAlt. \\
\hline Урбаністика & Scale approach to urban studies with GIS-tools & $\begin{array}{l}\text { gVis, mSci; aSpAn, 3D; mSci, mAnlst, aDMen, } \\
\text { aTemp, gImEx, mMngm, aDMen. }\end{array}$ \\
\hline Урбаністика & $\begin{array}{l}\text { The smart city infrastructure development } \\
\& \text { monitoring }\end{array}$ & $\begin{array}{l}\text { MVrfe, mMngm, mInstr, aModl, mMon, gVis, } \\
\text { gInOut, aIntD, gCoo. }\end{array}$ \\
\hline Урбаністика & $\begin{array}{l}\text { Geographic Information Science I: Why does a smart } \\
\text { city need to be spatially enabled }\end{array}$ & $\begin{array}{l}\text { mEng, mRealiz, mInf, mInv, mProf, mMon, } \\
\text { mPlan. }\end{array}$ \\
\hline Урбаністика & $\begin{array}{l}\text { A GPS/GIS Integrated System for Urban Traffic } \\
\text { Flow Analysis }\end{array}$ & $\begin{array}{l}\text { ASpAn, aModl, mAnlst, gGPS, mMngm, mProf, } \\
\text { gVis, aMap, mMon, gMetr, gCoo, gGraph. }\end{array}$ \\
\hline Урбаністика & $\begin{array}{l}\text { Loose-coupling a cellular automaton model and } \\
\text { GIS... }\end{array}$ & AModl, aIntD, 3D, aMap, gVis, gGeoPr. \\
\hline Урбаністика & $\begin{array}{l}\text { A GIS-based decision support system for planning } \\
\text { urban transportation policies }\end{array}$ & $\begin{array}{l}\text { mAuto, mAnlst, gInOut, mVrfc, gVis, gGeoPr, } \\
\text { aIntD, aMap, mProf, aModl, mMark, mDSupp, } \\
\text { mPlan, aSpAn, mMngm, aDMen. }\end{array}$ \\
\hline Урбаністика & 3D-GIS for Urban Purposes & 3D, mAnlst, gVis, gGraph, aModl, aGen, mPlan. \\
\hline Урбаністика & Ontologies and Knowledge Sharing in Urban GIS & mAnlst, aPrg, mInf, aDMen. \\
\hline Урбаністика & $\begin{array}{l}\text { GIS-based modelling for the estimation of municipal } \\
\text { solid waste generation and collection }\end{array}$ & $\begin{array}{l}\text { mAnlst, gGPS, mEcon, gDtColl, aMap, gCoo, } \\
\text { aPrg, aIntD, mInf, aModl, mMon, mMark, } \\
\text { mDSupp, mInstr, aSpAn, mMngm, aDMen. }\end{array}$ \\
\hline Урбаністика & $\begin{array}{l}\text { An assessment of Public Participation GIS and Web } \\
2.0 \text { technologies in urban planning practice... }\end{array}$ & $\begin{array}{l}\text { gInOut, gVis, gDtColl, aPrg, aMap, mColl, } \\
\text { mCons, gCoo, mInstr, mEng. }\end{array}$ \\
\hline Урбаністика & $\begin{array}{l}\text { Bike sharing station placement leveraging } \\
\text { heterogeneous urban open data }\end{array}$ & $\begin{array}{l}\text { mAnlst, gDtColl, mPrSolv, gGraph, aSpAn, } \\
\text { mMngm. }\end{array}$ \\
\hline Урбаністика & Функции городов и их влияние на пространство & $\begin{array}{l}\text { mAnlst, gVis, mPrSolv, gGeoPr, aIntD, aIntM, } \\
\text { aMap, mProf, aModl, aGen, aSpAn, mPlan, } \\
\text { mFcast, mMngm. }\end{array}$ \\
\hline Урбаністика & $\begin{array}{l}\text { Demographic dimension of suburbanization in } \\
\text { Ukraine in the light of urban development theories }\end{array}$ & MAnlst, gVis, mSci, aMap, mVision, aSpAn. \\
\hline Урбаністика & $\begin{array}{l}\text { GIS-based approach for optimized siting of municipal } \\
\text { solid waste landfill. Waste Management }\end{array}$ & $\begin{array}{l}\text { MDSupp, aSpAn, aMap, aIntD, gGeoPr, mRealiz, } \\
\text { mPlan, mProf, mMngm, mAnlst, aGen, gGraph, } \\
\text { aModl, gVis, aDMen, mCons, mMark, gInOut, } \\
\text { gCoo. }\end{array}$ \\
\hline Фотограмметрія & $\begin{array}{l}\text { Remote Sensing and GIs for Urban Growth Analysis } \\
\text { in China }\end{array}$ & $\begin{array}{l}\text { 3D, MAnlst, mPrRev, gVis, gDisp, gGPS, mSci, } \\
\text { gDtColl, mEng, mInf, aMap, aModl, mMon, } \\
\text { mMark, mPlan, aSpAn, mAva, mMngm. }\end{array}$ \\
\hline
\end{tabular}

\section{Таблиця 5. Перелік функцій у навчальних виданнях}

\begin{tabular}{|l|l|l|}
\hline Галузі знань або науки & \multicolumn{1}{|c|}{ Назва джерела } & \multicolumn{1}{|c|}{ Функції ГIC } \\
\hline Геоінорматика & Павленко Л. А. Геоінформаційні системи & aModl; gGeoPr, aDMen, aModl, mVrfc. \\
\hline Геоінформатика & Геоінформаційні системи. Підручник & mAnlst, gVis, aMap, gGraph, gGeoPr; gMetr \\
\hline Геоінформатика & $\begin{array}{l}\text { Основи геоінформаційних систем і технологій: } \\
\text { навчальний посібник }\end{array}$ & $\begin{array}{l}\text { GInOut; gQer, mMngm, mAnlst, gVis, gGraph, } \\
\text { aIntD. }\end{array}$ \\
\hline Геоінформатика & $\begin{array}{l}\text { Географічні інформаційні системи та технологіï: } \\
\text { підручник }\end{array}$ & $\begin{array}{l}\text { mAnlst, gInOut, mVrfc, gVis, gGeoPr, gGraph, } \\
\text { mRef, mSci, aIntD, mEng, mInstr, aMap, gMetr, } \\
\text { gClass, mProf, mMark, aModl, gDtTr, gCoo, } \\
\text { mDSupp, aSpAn, aStAn, mMngm. }\end{array}$ \\
\hline Геоінформатика & Просторовий аналіз і моделювання в ГIC & $\begin{array}{l}\text { mAnlst, gInOut, mVrfc, gVis, aGen, gGeoPr, } \\
\text { mPrRev, mEcon, aMap, gMetr, aModl, mOrg, } \\
\text { mOpt, mMark, mDSupp, mEng, aDMen. }\end{array}$ \\
\hline Геоінформатика & $\begin{array}{l}\text { Рrinciples of Geographic Information Systems : An } \\
\text { introductory textbook }\end{array}$ & $\begin{array}{l}\text { mAnlst, mVrfc, gVis, gQer, aMap, gMetr, gCoo, } \\
\text { aModl, mMon, aGen, gDtTr, aApl, aSpAn, } \\
\text { aDMen, mVision. }\end{array}$ \\
\hline Геоінформатика & GIS designing: Textbook & $\begin{array}{l}\text { mAnlst, gDisp, gVis, mRealiz, mInstr, aIntD, } \\
\text { aMap, mEng, aApl, mInstr, aSpAn, aAlt, aTemp, } \\
\text { mMngm, aDMen. }\end{array}$ \\
\hline Геоінформатика & Ocнови ГІС-аналізу: навч. посібник. \\
\hline Урбаністика & Digital tools in participatory planning & $\begin{array}{l}\text { a3D, mAnlst, gVis, gGeoPr, gGraph, mEcon, } \\
\text { gQer, aMap, gMetr, gClass, gCoo, aModl, } \\
\text { aDep, mOrg, mDSupp, mPlan, aSpAn, mMngm, } \\
\text { aDMen, aTemp. }\end{array}$ \\
\hline
\end{tabular}


Стаття [Venigalla, 2007] найбільш наближена до теми дослідження і містить досить повний перелік функцій саме муніципальних ГІС із зазначенням ïx можливого використання. Щоправда, чіткої класифікації цих функцій не наведено. Досить повний набір функцій викладений у статті [Arampatzis 2004], в якій викладено можливості ГІС для певної області прикладення - обслуговування транспортних мереж.

3 іншої сторони, всі публікації по темі дослідження, як правило, лише частково описують вказану предметну область. Із них важко скласти цілісне уявлення про функції муніципальних ГІС. Ця обставина має компенсуватись більш широкими критеріями пошуку та аналізу видань із різних галузей знань (ГІС, екології, урбаністики та ін.). До першої належать статті Koninger A, Clarke; до другої - Ghose M. K i Kanchanabhan T. Е.; до урбаністики - Al-Hader; державного управління - Carrizales T.; технологій Bhambulkar A. V.; дистанційного зондування - Chen S; інформатики - Drobne S.; наук про Землю - Melnyk L.

Методика дослідження полягала в аналізі наукових праць та навчальної літератури, виокремлення функцій муніципальних ГІC, узагальнення їх назв, класифікації та підрахунку частоти використання.

Вихідними джерелами стали опубліковані результати переважно іноземних i певна кількість праць вітчизняних фахівців щодо використання геоінформаційних систем для вирішення прикладних задач місцевого (не загальнодержавного) рівня. Додатково вивчалися статті з проектування і розроблення регіональних, міських та муніципальних ГІС. Уточнення предмету дослідження і співставлення результатів підрахунку здійснювали по підручникам та посібникам із геоінформатики.

Процес дослідження побудований за ітераційною схемою, а тому не має часових етапів.

Найбільш складною i протиречивою із методичної точки зору частиною дослідження $\epsilon$ виокремлення понять, які семантично співпадають $i$ з функиіями вказаного класу геоінформаційних систем. Складність полягає у приналежності ГІС до інтерактивних комп'ютерних систем, а не до автоматичних комплексів. Відповідно, функції ГІС цілком визначатимуться способом її використання. Наприклад, обробка просторових даних - це функція ГIC, як і підтримка прийняття рішень, складання проектів, організація активістів. Тобто функцією ГІС вважатимемо задачу, яка виконуються із залученням цієї системи, в якій роль останньої є вагомою для успішного вирішення цієї задачі.

Не всі функції явно вказані у текстах статей. Наприклад, фраза «налагодження співробітництва між владою і громадами» означає колабораційну діяльність. В деяких статтях об’єкт пошуку виокремлювався із супровідної графіки (візуалізація, картографічна, відображення даних) або матеріалів дослідження (введення даних, імпорт-експорт, картометрична), суті самої статті (дослідницька, імплементаційна, комерційна).

Із попередніх розвідок проявилась проблема неоднозначного трактування терміну «функція» і його злиття із поняттями «властивість», «спосіб використання», «призначення» $\mathrm{i}$ «виробничий процес». Наприклад, у фрагменті «збір, збереження, обробка, доступ, відображення й поширення просторових даних» [Павленко, 2013, с. 6] перераховуються виробничі або технологічні процеси, які одночасно можна трактувати як функції.

Складання таблииі уніфікациї функиій. Точне формулювання понять і термінів становить суттєву наукову проблему. Як правило, назви функцій, наведені авторами у опублікованих роботах, суттєво відрізняються за формулюванням. Автори не завжди використовують офіційну термінологію. Причиною цього $є$ недостатня їх освіченість у геоінформатиці, неточність формулювання фраз, відсутність відповідних нормативних документів, перенесення термінології з іншої галузі знань, розбіжності у розкритті цього питання в навчальних матеріалах. В результаті такого підходу в статтях зустрічаємо словосполучення на зразок «overlay analysis» [Sumathi at. all., 2008], який $\epsilon$ складовою просторового аналізу.

Виходячи 3 великої кількості прикладних задач, неточності формулювання назв функції муніципальних ГIC, потребою зробити їх назви компактними, вбачаємо потребу в уніфікації назв предмету дослідження шляхом складання відпо-відної таблиці. Кільком прикладам назв функцій із різних джерел відповідатимуть одна компактна назва, індекс (для вказівки на неї в інших таблицях) та число її вживань у розглянутих джерелах (статтях та книжках відповідно). Індекс функції є іï англомовним розбірливим (із використанням асоціацій) скороченням, призначенням для зменшення обсягу таблиць із вказанням переліку функцій, знайдених у джерелах. Ці таблиці призначені для саме для підрахунку частоти вживань функцій.

Оскільки передбачається віднайти нові функції муніципальних геоінформаційних систем (та способи їх використання), останні апріорі матимуть неточне формулювання.

Одночасно із таблицею уніфікації має бути заповнена таблиця переліку функцій.

Із вище викладеного можна зробити висновок, що виявлення функцій - задача достаньо творча; статистичне опрацювання отриманих результатів має обмежити їх перелік.

Результати. Після опрацювання 55 джерел всі функції ГІС поділені за на три категорії.

Перша категорія отримала назву «системні»; до неї віднесені функції, типові для ГІС і пов'язані 3 роботою геоінформаційних систем як комп'ютерних програм (таблиця 1). Це запити, які автори публікацій використовують для пошуку об'єктів за вказаними критеріями або збір даних, під час якого ГІС використовується в ролі засобу для введення 
і збереження інформації в електронній пам'яті. Найбільш популярною функцією є візуалізація виведення на екран геопросторових даних в одній iз систем географічних координат. Саме наявність системних функцій радикально відрізняє ГІС від графічних програм або текстових процесорів та електронних таблиць. В останніх передбачена можливість візуалізувати дані у вигляді графіків. Ще одною важливою системною функцією $є$ картометрична - вимірювання геометричних параметрів об'єктів і просторових відношень між ними (відстаней, кутів) та визначення координат. До цієї категорії можна віднести геопривязку визначення просторових координат за описовою інформацією (поштовою адресою).

У свою чергу, системні функції можна згрупувати у категорії, пов'язані із маніпулюванням даними (введення-виведення, імпорт-експорт, збір даних, запити і перетворення даних), графікою (візуалізація, відображення даних, картометрія), геопростором (геоприв'язка, геообробка, трансформування координат) та іншими, які не ввійшли до жодної 3 категорій (класифікація).

Слід зауважити, що геолокацуія та трансформування координат 3 технічної точки зору реалізуються майже однаково, проте автори публікацій їх розділяють.

Наступна семантична категорія функцій називається прикладні (таблиця 2). Від попередньої групи (системних) вона відрізняється наявністю готового до практичного використання результату роботи. Наприклад, відображення даних із системних функцій співвідносна із картографічною (прикладною). В результаті роботи їх обох отримуємо зображення певного явища на карті. Проте різниця між ними така, як між засобами i способами картографічного зображення. Наприклад, відобразити явище на карті можна за допомогою певних засобів зображення - точок, ліній, поверхонь. Картографічна функція передбачає виведення вихідних даних за допомогою певного способу картографічного забраження (ізоліній, ареалів).

Найбільш популярною у дослідників є функція моделювання. В результаті іiі роботи отримуємо просторову модель дійсності, найчастіше карту або тривимірну модель.

Управління даними передбачає створення закінченого продукту - набору даних. Доповнює цю функцію інтеграція даних - поєднання різнорідної інформації у набір і подальше використання останніх для створення карт або здійснення розрахунків. Прикладні функції геосистем досить повно викладені у спеціалізованій (керівництва користувача) та навчальній літературі.

Решта функцій $є$ важливими 3 точки зору соціальної та економічної географії та 3 їх аналізу можна більш повно оцінити важливість розроблення муніципальних ГІС. Робоча назва цих функцій високорівневі (таблиця 3).

Найбільш популярними є аналіз, управління, планування $і$ підтримка прийняття рішень. Аналіз передбачає перегляд, порівняння зображень, вивчення певних сторін об'єкта, в даному випадку за допомогою геоінформаційної системи, в результаті чого спеціаліст отримує певні висновки стосовно об'єкту аналізу.

Підтримка прийняття рішень досить детально викладена у літературі по геоінформаційних системам. Ця функція передбачає як обгрунтування (економічне, технічне) вже прийнятого рішення, так і надання інструментів та отримання відповідей на певні питання, пов'язані з формуванням рішення. Як правило, ці питання пов'язані зі сторонами рішення, які спеціаліст не може розв'язати в силу природних розумових обмежень. Геоінформаційні системи, наприклад, дозволяють працювати з просторовими даними і відображають їх у природній для людини формі сприйняття - у вигляді графічного образу. Оскільки встановлювати просторові відношення із координат об'єктів для людини невластиво.

Функція управління передбачає прийняття серії раціональних рішень, виходячи із наявних проблем і засобів для їх розв'язання. Ця категорія пов'язана з плануванням як передбаченням майбутніх проблемних питань, так і визначенням пріоритетних задач, вирішення яких становитиме користь для розвитку території муніципалітету.

Суттєво менш популярними функціями муніципальних геоінформаційних систем, на які посилаються автори приблизно у 25\% публікацій, $\epsilon$ такі:

Дослідницька або наукова - передбачає використання геосистем для вирішення задач, які не можуть бути вирішені іншими методами (адміністративними) i потребують здійснення наукових досліджень 3 метою вироблення і обгрунтування рішення.

Функція проектування (складання проектів) частково співвідносна із розробленням продуктів; останній процес в іноземній літературі називають «інжиніринг». Їх доповнює імплементаційна функція, яка передбачає реалізацію проектів та їх впровадження. Автори прикладних досліджень (практики) приділяють увагу автоматизаціiі виробничих і управлінських процесів.

Перераховані вище функції є загальновідомими i питання щодо їх важливості не виникає. Проте менш затребувані способи використання муніципальних ГІС означають певні перспективи роботи у цьому напрямі.

Наприклад, консолідаційна функція означає об'єднання розрізнених елементів для виконання важливих задач. Пристосовно до ГIC передбачається створення платформи чи «майданчика» для надання фізичної можливості одиницям муніципалітету взаємодіяти між собою. Такими одиницями можуть бути як підприємства, так і жителі території. Це може бути доцільним за умов стихійного лиха, наприклад. 3 іншої сторони, спрямування добровільної діяльності ентузіастів у чітко визначеному напрямі дозволяє виконувати ту ж роботу суттєво меншими зусиллями. Прикладом такої діяльності є прокладання комп'ютерних мереж. В той же час зекономлені кошти можуть 
бути спрямованими на придбання важливих матеріальних засобів.

Споріднена колабораиійна функція передбачає налагодження співробітництва між місцевими органами i громадянами. На відміну від інших програмних засобів на зразок E-Government (Carrizales Т., 2008), використання ГІС дозволяє геокодувати звернення і побачити їх розподіл по підконтрольній території. Такий підхід дозволяє оцінити характер проблеми та її локалізацію. Також полегшує планування діяльності, оскільки дозволяє побачити перспективні її напрями.

До цієї категорії можна віднести адміністративну функцію (здійснення управлінської діяльності органів влади), комунікаційну та організаційну. Вони являють собою варіації викладених вище понять.

$$
\text { Верифікація в }
$$

муніципальних геоінформаційних системах грунтується на зміні способу відображення інформації. Перехід від табличного або текстового до просторового (графічного, двовимірного) представлення дозволяє виявити певні помилки, недоступні для інших методів перевірки. До таких неточностей належать похибки у геоданих (координатах), адресах або просторовому описі. Такожце атрибутивніпомилки. Відображення останніх за допомогою одного із способів картографічного зображення дозволяє відразу встановити промахи. Тобто верифікація за допомогою ГІС розрахована перш за все на виявлення грубих, очевидних неточностей, які можуть бути виявлені візуальним способом після відображення даних на моделі. Крім зміни форми представлення даних виявленню помилок може сприяти зміна розмірності засобу картографічного зображення. Об'єкт, локалізований в точках, можна представити у вигляді неперервного поля відображуваного явища. Споріднене поняття зміна способу картографічного зображення.

Екзотичними способами використання муніципальної ГІС є формування бачення [на певну проблему] і формування світогляду [цільової аудиторіi] загалом. Обгрунтування пропонованого рішення за допомогою карти або картосхеми $є$ віддзеркаленням сприйняття проблеми спеціалістом та його бачення шляху вирішення останньої. Крім того, такий матеріал може використовуватись для «м'якого» нав'язування пропонованого рішення, оскільки не всі люди мають розвинені творчі здібності і цілеспрямовано шукатимуть альтернативи.

Творчу функцію винесено в прикладні, не дивлячись на те, що вона має відношення до формування і прийняття рішення, проте результат iii роботи визначений нечітко. В розглянутих працях вона знадується неявно, у вигляді «пошук альтернативних рішень».

Формування світогляду [цільової аудиторії] полягає у нав'язуванні підходу до вирішення такого роду проблем. Наприклад, використання ГІС в міському плануванні. Не дивлячись на те, що для цієї цілі цілком придатні системи автоматизованого проектування, які значно потужніші і надійніші у використанні. Або векторні графічні редактори, які дозволяють високоякісно оформлювати результати роботи.

Вказаний підхід у вирішенні проблеми, який виявляється ефективним, передбачає затребуваність спеціалістів для виконання такого роду задач. Це впливає на зайнятість населення. Особливо слід відмітити самозайнятість і волонтерську (непрофесійну) діяльність, яка формує певний клас спеціалістів.

Відносно часто у наукових та навчальних матеріалах зустрічається використання ГІС для комериійних задач, тобто отримання прибутку.

До початку дослідження вважалось, що роль ГІС у підтриманні у справному стані інфраструктури території буде досить високою. Проте на пострадянському просторі для обслуговування комунікацій послуговуються крупномасштабними планами, зробленими у системах автоматизованого проектування. Іноземні автори описують використання для цих цілей не муніципальних, а ГІС міст як більш компактних і цілісних об'єктів, а не визначених шляхом адміністративного, тобто не зовсім природнього поділу. Відповідно, функція обслуговування інфраструктури виявилась незатребуваною.

Одноюз корисних особливостей ГІСє реалізована ними можливість моніторингу - відображення інформації (переважно в картографічному вигляді) в реальному часі або через визначені проміжки останнього.

Функція оцінки входить до аналізу, проте у восьми працях вона зустрічається окремо.

Решта функцій, серед яких загальновідомі надання послуг населенню, оптимізація рішень, організаційна, інноваційна входіть до відповідних більш крупних категорій (комерційної, управління та наукової), тому в наукових джерелах згадуються нечасто.

Обговорення результатів. Розподіл функцій муніципальних геоінформаційних систем на системні, прикладні та високорівневі доволі дискусійний та умовний. Високорівневі функції можна назвати адміністративними, проте ця назва охопить лише їх частину. Також немає чіткого групування за рівнем функції (від низькорівневих системних до високорівневих управлінських): всі вони приблизно рівномірно розподілені по цій шкалі. Можна сказати, що всі функції можна поділити на «власне геоінформаційні», до яких належать оброблення геопросторових даних, просторовий аналіз та автоматизоване картографування та похідні, пов'язані з використанням цієї технології: управління та комерційна.

Часто в окремих частинах навчальних i наукових робіт функції ГІС викладені з прикладної точки зору, що є необхідним для розкриття певної теми. Наприклад, у праці [Остроух, Даценко, 2011] автори вказують наступне призначення ГІС: «...в аналізі таких глобальних проблем, як перенаселення, забруднення довкілля ... ; при рішенні окремих задач, 
серед яких, наприклад, логістичні задачі, підбір оптимального розташування нового офісу, пошук будинку за його адресою, прокладання трубопроводу, різні муніципальні завдання і землекористування». Всі ці задачі належать до просторового аналізу.

Виявлення функцій муніципальних ГІС має ще одну проблему - різну «вагу», «масштаб» чи «калібр» функції. Наприклад, «управління» потенційно включає в себе прийняття рішень, аналіз, отримання інформації (генерацію даних) i, насамкінець, планування. Ця категорія частково корелює із практичним ефектом. Візуалізація важливіша від введення даних, а користь від підримки прийняття рішень відома всім.

«Спектр» функцій означає ступінь їх приналежності до категорій, пов'язаних із виробничим процесом, наприклад, машини та оператора. Управління, аналіз, верифікація - це більш «людські» функції. В той час як візуалізація, експорт і перетворення координат більше тяжіють до машинних функцій. Цей факт слід врахувати під час виявлення і класифікації функцій.

«Геообробка» частково корелює із «отриманням інформації». «Візуалізація» $є$ частковим випадком «введення-виведення даних». «Маніпулювання даними» - ця функція не має практичного ефекту, однак наближається за значенням до «геообробки» та «просторового аналізу», оскільки в результаті цих операцій ми отримуємо набір вихідних даних для виконання інших операцій.

В деяких джерелах одна вказана операція може належати до кількох категорій. Наприклад, «оцінка економічної ефективності діяльності видобувної компанії» - це оцінка та економічна функції. «Економія засобів та ресурсів» - теж, начебто, функція економічна.

Висновки. Таким чином популярність геоінформаційних систем зумовлена такими факторами:

- інтеграцією різнорідних даних та функцій 3 їх оброблення та візуалізації в одному програмному комплексі;

- перенесенням у віртуальне середовище невластивих для людини операцій;

- відносно простим візуальним програмним інтерфейсом.

Так чи інакше, графічні та аналітичні машинні функції доповнюють розумові здібності оператора, для яких нехарактерно оперування великими масивами числової інформації та великою кількістю об'єктів. Геоінформаційні системи перетворюють незручні числові дані в придатний для ментальної обробки графічний вигляд. Графічна форма виведення даних подібна до картини світу, яку сприймає людина. В цьому і полягає головна функція та перевага геоінформаційних систем.

Як перспективу подальших досліджень можна запропонувати виконання анкетування аудиторії потенційних користувачів на предмет затребуваності функцій муніципальної ГІС i формування потреб потенційних користувачів у зручних інструментах управління розвитком територій.

\section{References:}

1. Al-Hader M., Rodzi A. The smart city infrastructure development \& monitoring. Theoretical and Empirical Researches in Urban Management, 2009, Vol. 4, No. 2 (11), pp. 87-94.

2. Arribas-Bel D. Accidental, open and everywhere: Emerging data sources for the understanding of cities. Applied Geography, 2014, Volume 49, pp. 45-53.

3. Arampatzis G., Kiranoudis C.T., Scaloubacas P., Assimacopoulos D. A GIS-based decision support system for planning urban transportation policies. European Journal of Operational Research, 2004, Vol. 152, pp. 465-475.

4. Bhambulkar A. V. Municipal solid waste collection routes optimized with ArcGIS Network Analyst. International Journal of Advanced Engineering Sciences and Technologies, 2011, Vol. 11, Issue 1, pp. $202-207$.

5. Bugs G., Granell C., Fonts O., Huerta J., Painho M. An assessment of Public Participation GIS and Web 2.0 technologies in urban planning practice in Canela, Brazil. Cities, 2010, Vol. 27, pp. 172-181.

6. Carrizales T. Functions of E-Government: A Study of Municipal Practices. State and Local Government Review, 2008, Vol. 40, No. 1, pp. 12-26.

7. Chen L. et. al. Bike sharing station placement leveraging heterogeneous urban open data. Proceedings of the 2015 ACM International Joint Conference on Pervasive and Ubiquitous Computing. Osaka, Japan — September 07 - 11, 2015, pp. 571-575.

8. Chen S., Zeng S., Xie C. Remote Sensing and GIS for Urban Growth Analysis in China. Photogrammetric Engineering \& Remote Sensing, 2000, Vol. 66, No. 5, pp. 593-598.

9. Clarke K. C., Gaydos L. J. Loose-coupling a cellular automaton model and GIS: long-term urban growth prediction for San Francisco and Washington/Baltimore. Geographical Information Science, 1998, Vol. 12, N. 7, pp. 699-714.

10. Gnatiuk O. M. Prostorovì transformaciï urbanìzovanih teritorìj Ukraïni periferìjno-ìndustrìal'nogo tipu (na prikladì mìst Zaporìžžâ ì Žovtì Vodi) [Space transformations of urban peripheral and industrial areas in Ukraine (on the example of cities of Zaporizhia and Zhovti Vody)]. Visnyk of Karazin Kharkiv National University, series “Geology. Geography. Ecology”, 2017, Vol. 46, pp. 68-74. (In Ukrainian).

11. Dacenko L. M., Ostrouh V. Ì. Osnovi geoìnformacìnih sistem ì tehnologìj: navčal'nij posibnik [Fundamentals of geoinformation systems and technologies: tutorial]. Kyiv: DNVP Kartohrafiya, 2013, 184 p. (In Ukrainian). 
12. Demìhov O. Geoìnformacìjna sistema âk mehanìzm modelûvannâ upravlìns'kih rìšen' munìcìpalìtetu v sferì zabezpečennâ efektivnostì ìnfrastrukturi mìsta [Geographic information system as a mechanism for modeling management decisions of the municipality in the field of ensuring the city's infrastructure efficiency]. Actual Problems of Public Administration, 2016, Vol. 3 (67), pp. 128-131. (In Ukrainian).

13. Digital tools in participatory planning / ed. S. Wallin, L. Horelli, J. Saad-Sulonen. Espoo: Centre for Urban and Regional Studies Publications, 2010, 142 p.

14. Dorožins'kij O., Kolb İ., Dorožins'ka O. Geoìnformacìjnì tehnologiiï v realìzaciï zavdan' munìcipal'noï vladi ì rekreacìnoï diâl'nostì [Geoinformation technologies in the realization of the tasks of the municipal authority and recreational activity]. Geodesy, Cartography and Aerial Survey, Vol. 68, 2007, pp. 60-65. (In Ukrainian).

15. Drobne S., Lisec A. Multi-attribute Decision Analysis in GIS: Weighted Linear Combination and Ordered Weighted Averaging. Informatica, 2009, 33, pp. 459-474.

16. Fonteca F. T., Egenhofer M. J., Davis C. A., Borges K. A. Ontologies and Knowledge Sharing in Urban GIS. Computer, Environment and Urban Systems, Vol. 24, Issue 3, 31 May 2000, Pages 251-272.

17. Funkcii gorodov $i$ ih vliânie na prostranstvo [Functions of cities and their influence on space]. (Ed. L.G. Rudenko). Kyiv: Fenix, 2015, 292 p. (In Russian).

18. Ghose M. K., Dikshit A. K., Sharma S. K. A GIS based transportation model for solid waste disposal A case study on Asansol municipality. Journal of waste management, 2006, Vol. 26 (11), pp. 1287-1293.

19. Gnatiuk O. Demographic dimension of suburbanization in Ukraine in the light of urban development theories. Acta Universitatis Carolinae Geographica, 2017, Vol. 52, No 2, pp. 13-25.

20. Gorai A. K. Kumar S. Spatial Distribution Analysis of Groundwater Quality Index Using GIS: A Case Study of Ranchi Municipal Corporation (RMC) Area. Geoinformatics \& Geostatistics: An Overview, 2013, Vol. 1, Issue 2, pp. 1-11.

21. Haklay M. How good is volunteered geographical information? A comparative stady of OpenStreetMap and Ordance Survey datasets. Environment and Planning. B: Planning and Design, 2010, Vol. 37, pp. 682-703.

22. İŝuk O. O., Koržnev M. M., Košlâkov O. Ê. Prostorovij analìz ì modelûvannâ v GİS: Navčal'nij posìbnik [Spatial analysis and modeling in GIS: Manual]. (Ed. M. D. Grodzins'kij). Kyiv: Publishing and Printing Center "Kyiv University", 2003, 200 p.

23. Kanchanabhan T. E., Mohaideen J. A., Srinivasan S., Sundaram L. K. Optimum municipal solid waste collection using geographical information system (GIS) and vehicle tracking for Pallavapuram municipality. Waste Management \& Research, 2011, Vol. 29(3), pp. 323-339.

24. Kao J.-J., Lin H.-Y. and Chen W.-Y. Network geographic information system for landfill siting. Waste Management \& Research, 1997, Vol. 15, pp. 239-253.

25. Karadimas N. V., Loumos V. G. GIS-based modelling for the estimation of municipal solid waste generation and collection. Waste Management Research, 2008, Vol. 26, pp. 337-346.

26. Koninger A. 3D-GIS for Urban Purposes. GeoInformatica, 1998, Vol. 2, N. 1, pp. 79-103.

27. Kostrikov S. Scale approach to urban studies with GIS-tools. Human Geography Journal, 2014, Vol. 17 (2), pp. 52-60.

28. Kostrikov S, Kulakov D., Segida K. Programne zabezpečennâ GÌS dlâ LIDAR-tehnologï distancìjnogo zonduvannâ v cìlâh analìzu urboekosistem [GIS-software for the lidar-technology remote sensing in urbogeosystem analysis research purposes]. Problemi bezperervnoï geografičnoï osviti i kartografï [The Problems of Continuous Geographical Education and Cartography], 2014, Vol. 19, pp. 45-52. (In Ukrainian).

29. Kushniruk T., Lobanova O. Geoìnformacìjnì sistemi ì tehnologïi v upravlìnnì munìcipal'nih utvoren' [The geoinformation systems and technologies in the municipalities' formations operation]. Visnik L'vìv'kogo nacional'nogo agrarnogo universitetu. Seriâ: Ekonomika APK [Visnyk of Lviv National Agrarian University. Series: Economy of agroindustrial complex], 2016, Vol. 23(2), pp. 142-149. (In Ukrainian).

30. Labenko D.P., Tìmonìn V.O. Geoìnformacìjnì sistemi. Pìdručnik [Geographic information systems. Textbook]. Kharkiv, 2012, 260 p. (In Ukrainian).

31. McKinney D. C., Cai X. Linking GIS and water resources management models: an object-oriented method. Environmental Modelling \& Software, 2002, Vol. 17, pp. 413-425.

32. Melnyk L., Oreshchenko A., Batychenko S. Transformaciï mìs'kogo prostoru na prikladì testovoï dìlânki v misti Luc'k [The urban space transformation of Lutsk as an example]. Bulletin of Taras Shevchenko National University of Kyiv. Geography, 2016, Vol. 1(64), pp. 53-57. (In Ukrainian).

33. Melnichuk A., Rastvorova M. Use of GIS in urban territory development research. Human Geography Journal, 2014, Vol. 17 (2), pp. 167-170.

34. Oreshchenko A., Nesterchuk I. Development and use of a geoinformation system for revealing urban problems. Eastern-European Journal of Enterprise Technologies, 2017, Vol 2, Issue 2, pp. 32-41.

35. Ostroukh V., Datsenko L. Navčal'nij posibnik «Osnovi geoìnformacìjnih sistem ì tehnologìj» âk priklad realìzacïi sučasnih metodìv navčannâ v kontekstì ìnformatizacïi osvìti [Training aid "Basics of Geoinformation Systems and Technologies" as an example implementation of modern teaching methods in the context of education informatization]. Problemi bezperervnoï geografičnoï osvìti i kartografï [The Problems of Continuous Geographical Education and Cartography], 2011, Vol. 13, pp. 68-70.

36. Palekha Y. N. Razvitie gradostroitel'nyh GIS na sovremennom ètape [Development of urban GIS in Ukraine 
at the present stage]. Scientific Notes of Taurida National V.I. Vernadsky University. Geography Series, 2010, T. 23 (62), № 2, pp. 214-221. (In Russian).

37. Pavlenko L. A. Geoinformacìjnì sistemi: navčal'nij posibnik [Geographic information systems: tutorial]. Kharkiv, 2013, 260 p. (In Ukrainian).

38. Principles of Geographic Information Systems: An introductory textbook / ed. O. Huismann, R. A. de By. Enschede: The International Institute for Geo-Information science and Earth Observation, 2009, 540 p.

39. Pyrkova O.V. Theoretical aspects for use technologies formation and implementation of urban development land monitoring. Young Scientist, 2015, N. 10 (25), Part 1, pp. 18-20.

40. Roche S. Geographic Information Science I: Why does a smart city need to be spatially enabled? Progress in Human Geography, 2014, 38 (5), pp. 703-711.

41. Samoilenko V.M., Datsenko L. M., Dibrova I. O. GIS designing: Textbook. Kyiv: Print Service, 2015, 256 p.

42. Samojlenko V. M. Geografičnì ìnformacìnnì sistemi ta tehnologiï: pìdručnik [Geographic Information Systems and Technologies: Textbook]. Kyiv, Nika-Tsenkot, 2010, 448 p.

43. Šipulìn V. D. Osnovi GİS-analìzu: navčal'nij posibnik [Fundamentals of GIS analysis: manual]. Kharkiv, 2014, 330 p.

44. Shi W., Kong Q-J., A GPS/GIS Integrated System for Urban Traffic Flow Analysis. Proceedings of the 11th International IEEE Conference on Intelligent Transportation Systems (12-15 October, 2008, Beijing, China), pp. 844-849.

45. Sokolovska O. O. Smart City: vikoristannâ ìnformacìjno-komunìkativnih tehnologìj u mìscevomu samovrâduvannì [Use of information and communication technology in local self-government]. Public Administration Aspects, 2014, Vol. 11-12, pp. 77-85.

46. Sumathi V.R. Natesan U. Sarkar C. GIS-based approach for optimized siting of municipal solid waste landfill. Waste Management, 2008, Vol. 28, pp. 2146-2160.

47. Tanavud C., Yongchalermchai C., Bennui A., Bensreeserekul O. Assessment of flood risk in Hat Yai municipality, Southern Thailand, using GIS. Journal of Natural Disaster Science, 2004, Vol. 26, N. 1, pp. 1-14.

48. Tiwari A., Jain K. GIS Steering smart future for smart Indian cities. International Journal of Scientific and Research Publications, 2014, Vol. 4, Issue 8, pp. 1-5.

49. Chukut S., Dmytrenko V. Smart-sìti či elektronne mìsto: sučasnì pìdhodi do rozumìnnâ vprovadžennâ e-urâduvannâ na mìscevomu rìvnì [Smart city or electronic city: modern approaches to the understanding of the implementation of e-governance at the local level]. Investytsiyi: praktyka ta dosvid, 2016, No. 13, pp. 89-93. (In Ukrainian).

50. Fedoruk M. Ìnformacijnì sistemi mìst âk ìnstrument energoefektivnostì [Information systems as a tool for energy efficiency]. Visnyk of the Lviv University. Series Economics, 2014, Vol. 51, pp. 312-317. (In Ukrainian).

51. Udovychenko V., Melnychuk A., Gnatiuk O., Ostapenko P. Decentralization reform in Ukraine: assessment of the chosen transformation model. European Spatial Research and Policy, 2017, Vol. 24., N. 1., pp. 23-40.

52. Venigalla M. M., Baik B. H. GIS-Based Engineering Management Service Functions: Taking GIS beyond Mapping for Municipal Governments. Journal of Computing in Civil Engineering, 2007, Vol. 21, pp. 331-342.

53. Yano K., Nakaya T., Ishikawa Y. An Analysis of Inter-Municipal Migration Flows in Japan Using GIS and Spatial Interaction Modeling. Geographical Review of Japan, 2000, Vol. 73 (Ser. B), No. 2, pp. 165-177. 